\title{
Contents, Vol. 30, 1976
}

\section{No. 1-4}

Alexander, D.P.; Assan, R.; Button, H.G.;

Fenton, E., and Redstone, D.: Glucagon Release

in the Sheep Fetus. I. Effect of Hypo- and Hyper-

glycaemia and Arginine

Levitsky, L.L.; Speck, S.M., and Shulman, R.:

Metabolic Response to Fasting in Experimental

Intrauterine Growth Retardation. A Comparison

of Two Models

Rosen, K.G. and Isaksson, O.: Alterations in

Fetal Heart Rate and ECG Correlated to Glyco-

gen, Creatine Phosphate and ATP Levels during

Graded Hypoxia

Alexander, D.P.; Britton, H.G., and Buttle, H.L.: Prolactin in the Sheep Fetus: Effect of

Reserpine

Hahn, P.; Beatty, CM., and Bocek, R.M.: Carni-

tine Transferases in Brown Fat of Newborn and

Developing Primates

Gain, K. and Watts, C: Glucose Homeostasis in

the Developing Rat. II. Blood Glucose, Plasma

Insulin and Hepatic Glycogen in the Newborn

Rat

Frohlich, J.; Hahn, P.; Kirby, L·, and Webber, W.:

Rat Fetal Brown Adipose Tissue in vitro: Effects

of Hormones and Ambient Temperature. Com

parison with Rat Fetal Liver

Edwards, E.M.; Dhand, U.K.; Jeacock, M.K., and

Shepherd, D.A.L.: Pyruvate and Oxaloacetate

Metabolism in the Kidney Cortex of Developing

1 Sheep

49

Kajtár, P.; Jéquier, E., and Prod'hom, L.S.: Heat

Losses in Newborn Infants of Different Body

Size Measured by Direct Calorimetry in a Ther-

11 moneutral and a Cold Environment 55

Rubecz, I. and Mestyán, J.: Energy Metabolism

and Intravenous Nutrition of Premature Infants.

II. The Responses of Oxygen Consumption,

17 Respiratory Quotient and Substrate Utilization

to Infusion of Fat Emulsion 66 
25 Mestyán, J.; Rubecz, I., and Soltész, Gy.:

Changes in Blood Glucose, Free Fatty Acids and

Amino Acids in Low-Birth-Weight Infants Re

ceiving Intravenous Fat Emulsion $\quad 74$

30

Alexander, D.P., Bashore, R.A.; Britton, H.G., and Forsling, M.L.: Antidiuretic Hormone and Oxytocin Release and Antidiuretic Hormone

Turnover in the Fetus, Lamb and Ewe $\quad 80$ 35

Watts, C; Gain, K., and Sandin, P.L.: Glucose

Homeostasis in the Developing Rat. I. Blood

Glucose and Immunoreactive Insulin in the Later

Stages of Gestation of the Fetal Rat 88

IV

Contents

Rosen, K.G.; Hrbek, A.; Karlsson, K.; Kjellmer, I.; Olsson, T., and Riha, M.: Changes in the ECG and Somatosensory-Evoked EEG Responses during Intrauterine Asphyxia in the Sheep .... 95

Vízek, K.; Rázová, M, and Melichar, V.: Effect

of ACTH on Blood-Free Fatty Acids, Glucose

and on the Release of Free Fatty Acids from

Subcutaneous Adipose Tissue in Various Groups

of Newborns and Adults 102

Aprille, J.R. and Rulfs, J.: A Convenient Neo

natal Model for Developmental Studies Requiring

Artificial Diets 109

Gustke, H.-H. and Kowalewski, S.: Effect of Per-

fusion on the Biochemical Composition of the

Human Placenta 116

Rautenbach, M. and Beyreiss, K.: Absorption

Rates of Fructose and Influence of Fructose on

the Glucose Blood Level in Preterm and Term

Newborns Appropriate for Gestational Age as

Compared to Preterm and Term Newborns Small

for Gestational Age 123

Sunderland, CO.; Dhindsa, D.S.; Henken, D.P.; Nichols, G.M.; Met calfe, J.; Menashe, V.D., and Lees, M.H.: Respiratory Characteristics of Blood following the Interatrial Baffle Procedure for Dextro Transposition of the Great Arteries . . 156

Rosso, P.: Placental Transfer of $\alpha$-Amino Isobutyric Acid and Glucose Near Term and in Progesterone-Induced Prolonged Gestation in the

Rat 163

Shirley, D.G.: Developmental and Compensatory

Renal Growth in the Guinea Pig 169 
Hernandez, R.J.: Effect of Malnutrition and 6Hydroxydopamine on the Early Postnatal Devel opment of Noradrenaline and Serotonin Content in the Rat Brain $\quad 181$

Olusi, S.O.; Wallwork, J.C., and McFarlane, H: Intrauterine Malnutrition and IgG Allotypes in the Rat 187

Zondek, L.H. and Zondek, T.: Fetal Hilar Cells and Leydig Cells in Early Pregnancy 193

Taeusch, H. W. jr.; Patterson, A.; Williams, L., and Colle, E.: Plasma Glucocorticoid Concentrations after Injections of Heroin, Corticotrophin, Saline and Cortisol in Fetal and Neonatal Rabbits ...

131 Zondek, L.H. and Zondek, T.: Relationship be tween Concentrations of Human Chorionic Gonadotrophin (HCG) in Maternal Plasma, Amniotic Fluid and Fetal Cerebrospinal Fluid 200

Price, H.V.; Cowley, T., and Cameron, E.H.D.: Neonatal Hydrocortisone Administration: Effect on Cortisol and Glucose Levels 138 Robertson, A.F.; Karp, W.B., and Johnsson, J.: Human Placental Amino Acid Oxidation 142 Ferré, P. and Girard, J.R.: Alanine 14C Incorporation into Liver and Skeletal Muscle Proteins during the Early Postnatal Period in the Rat . . 145 Clark, J.F. and Clark, CM. jr.: Kinetics of Insu lin-Stimulated Accumulation of Glucose by Heart Cells from Newborn Rats 150 Di Marco, P.N.; Ghisalbertí, A.V.; Pearce, P.H., and Oliver, I.T.: Post-Natal Changes in Blood Glucose, Phosphopyruvate Carboxylase and Tyrosine Aminotransferase after Normal Birth and Premature Delivery in the Rat 205 Krauss, A.N.; Waldman, S., and Auld, P.A.M.: Diminished Response to Carbon Dioxide in Pre mature Infants 216

Froger, J.L.; Aminot, A.; Blouquit-Debray, M.F., and Roffi, J.: Antidiuretic Activity in the Fetal and Newborn Rabbit Hypophysis 224 Bell, J.U. and Van Petten, G.R.: Plasma Esterase Development in the Perinatal Lamb 232 Contents $\mathrm{V}$ 
Hoff, KM; Baker, PC; Presnell, V., and Rodville, $\mathrm{L} \cdot$ : Maturation of Indoleamine Metabolism in the Spinal Cord of the Mouse

Berry, D.H. and Brewster, M.A.: Riboflavin, FAD, Glutathione, and Active Glutathione Reductase in Neonatal Erythrocytes

Pass, R.; Christopher, C; Hinkley, C; Milstead, R.; Bailey, P., and Cassady, G.: Amniotic Fluid Volume in Pregnancies Complicated by Diabetes .

Dweck, H.S.; Brans, Y.W.; Sumners, J.E., and Cassady, G.: Glucose Intolerance in Infants of 238 Very Low Birth Weight. II. Intravenous Glucose

Tolerance Tests in Infants of Birth Weights 5001,380 Grams 261

245 Buckley, N.M.; Gootman, P.M.; Gootman, N.; Reddy, G.D.; Weaver, L.C., and Crane, L.A.: Age-Dependent Cardiovascular Effects of Affer ent Stimulation in Neonatal Pigs 268 250

Chowdhury, M. and Steinherger, E.: Sex Differ ence in de novo Synthesis of FSH in Developing Rats

255

Author Index Subject Index 280281 